\title{
Albatross overlap with fisheries in the Benguela Upwelling System: implications for conservation and management
}

\author{
Samantha L. Petersen ${ }^{1,2, *}$, Richard A. Phillips ${ }^{3}$, Peter G. Ryan ${ }^{2}$, Les G. Underhill ${ }^{4}$ \\ ${ }^{1}$ WWF Responsible Fisheries Programme, PO Box 50035, Waterfront, Cape Town 8001, South Africa \\ ${ }^{2}$ DST/NRF Centre of Excellence at the Percy FitzPatrick Institute of African Ornithology, University of Cape Town, \\ Rondebosch 7701, South Africa \\ ${ }^{3}$ British Antarctic Survey, Natural Environment Research Council, High Cross, Madingley Road, Cambridge CB3 0ET, UK \\ ${ }^{4}$ Animal Demography Unit, Department of Zoology, University of Cape Town, Rondebosch 7701, South Africa
}

\begin{abstract}
Trawl activity on the continental shelf break off South Africa provides large quantities of food in the form of discards for a range of species, including non-breeding black-browed albatrosses Thalassarche melanophrys and white-capped albatrosses T. steadi. As large numbers of both species are killed in collisions with trawl warp cables, mitigation measures have been introduced that include limitation of discards, yet little is known about the consequences of reduced food supply for scavenging birds. We tracked adult and immature albatrosses in the southern Benguela in the austral winters of 2005 and 2006 and examined their distribution in relation to fisheries, bathymetry and remotely sensed oceanography. Kernel analysis revealed that white-capped albatrosses spent most $(85.0 \%)$ of their time on the southern African trawl grounds, whereas black-browed albatrosses spent only $39.2 \%$ of their time in these areas, and the remainder on return oceanic foraging trips, typically of $8.4 \mathrm{~d}$ duration and $2540 \mathrm{~km}$ (max. $5320 \mathrm{~km}$ ) in length. While foraging in South African waters, the presence of trawlers was a strong predictor of albatross distribution. While on oceanic foraging trips, black-browed albatrosses moved predictably along the margins of eddies, typically areas of enhanced productivity and high prey concentrations. This study presents evidence that blackbrowed albatrosses forage to a much greater extent on natural prey than do white-capped albatrosses. Therefore, given the high incidence of albatross collisions with trawl cables, the benefit of a management decision to limit discarding as a mitigation measure is likely to outweigh the disadvantage of reduced food.
\end{abstract}

KEY WORDS: Seabird movements $\cdot$ Albatrosses $\cdot$ Satellite tracking $\cdot$ Longline $\cdot$ Trawl $\cdot$ Fisheries

\section{INTRODUCTION}

Albatrosses are K-selected, displaying high adult survival, delayed onset of first breeding and low reproductive rates (Warham 1996). Life-history characteristics reflect evolutionary responses to environmental conditions (Lack 1968) and have, in the case of albatrosses, been attributed to the sparse, patchy and unpredictable nature of the marine resources upon which they depend. In the non-breeding season, albatrosses are not restricted to waters within commuting distance of colonies, and often migrate long distances across ocean basins to feed in areas where food is presumably more predictable (Croxall et al. 2005, Phillips et al. 2005a). Bathymetric features such as continental shelves or sea-mounts, and oceanic frontal systems, are areas of enhanced marine productivity that are often targeted by foraging seabirds (Hunt \& Schneider 1987, Weimerskirch et al. 1993, Pakhomov \& McQuaid 1996, Nel et al. 2001, Phillips et al. 2005a).

Areas of high productivity are also commonly areas where commercial fisheries have developed. It is well 
documented that fisheries, particularly trawl, represent a substantial food source for opportunistic seabirds through the discarding of waste offal and nontarget catch (Abrams 1985, Furness et al. 1988, Ryan \& Moloney 1988, Garthe et al. 1996, Phillips et al. 1999, González-Zevallos \& Yorio 2006, Sullivan et al. 2006). Indeed, the presence of fisheries has been identified as an important determinant of seabird distribution at sea, and changes in fisheries practices can have major implications for seabird community structure (Wahl \& Heinemann 1979, Ryan \& Moloney 1988, Furness et al. 1992, Garthe 1997, Votier et al. 2004). Moreover, as albatrosses have limited diving ability (Prince et al. 1994), demersal trawl fisheries permit access to deep water resources, such as hake Merluccius spp., that would otherwise be unavailable. However, feeding on fisheries discards from trawlers or on baited longline hooks is associated with risk of injury or mortality (either through entanglement or becoming hooked and drowning) and is the leading cause of observed population declines in many albatrosses and petrels (Croxall \& Gales 1998, Sullivan et al. 2006, BirdLife International 2008). The degree to which albatrosses and petrels are dependent on this food source is unknown. Nevertheless, several studies of seabirds generally considered to rely heavily on discarding have found that natural prey are much more important across part or all of the range, or during certain times of year (e.g. Phillips et al. 1999, Cherel et al. 2002).

The upwelling system off the west coast of South Africa, known as the southern Benguela ecosystem, is one of the world's most productive marine ecosystems (Shannon \& Field 1985). Large-scale commercial longline and trawl fisheries for hake, and longline fisheries for tunas Thunnus spp., provide large amounts of fisheries discards, and as a consequence have led to longterm changes in the distribution of seabirds in the region (Abrams 1983, Duffy et al. 1987, Ryan \& Moloney 1988, Crawford et al. 1991). The South African Exclusive Economic Zone (EEZ) is a key foraging area for over-wintering and non-breeding black-browed Thalassarche melanophrys and white-capped T. steadi albatrosses (Brothers et al. 1998, Prince et al. 1998, Phillips et al. 2005a), which are of global conservation concern (Croxall \& Gales 1998, BirdLife International 2008). The black-browed albatrosses that over-winter in the Benguela region breed at South Georgia in the SW Atlantic Ocean, and at Crozet and Kerguelen in the Southern Indian Ocean, where populations have decreased dramatically since the mid-1970s (Croxall et al. 1998, Weimerskirch \& Jouventin 1998, Poncet et al. 2006). Although there are currently few reliable trend data for white-capped albatrosses at breeding colonies, both longline and trawl fisheries operating in the southern Benguela are having severe impacts on both species (Barnes et al. 1997, Ryan et al. 2002, Petersen et al. 2007, Watkins et al. 2008, S. L. Petersen et al. unpubl. data). It has been estimated that approximately 21000 birds are killed per year by the trawl and longline fisheries operating in South African waters (Petersen et al. 2007, Watkins et al. 2008, S. L. Petersen et al. unpubl. data).

Given the increasing concern worldwide about impacts on non-target species, many fisheries, including those operating in the Benguela ecosystem, have introduced mitigation protocols that aim to reduce incidental mortality of seabirds, turtles and sharks (Brothers et al. 1999, CCAMLR 2002, MCM 2007, Read 2007). These include improved discard management to reduce the attraction of seabirds to vessels, often in tandem with other measures. This, however, has potentially important resource implications, depending on the extent to which the affected seabirds rely, or can revert to feeding on natural prey. This study investigated the foraging strategies of non-breeding whitecapped and black-browed albatrosses in relation to fisheries, bathymetry and oceanographic features. Results are discussed in the context of likely responses of these species to a reduction in discard availability in the region.

\section{MATERIALS AND METHODS}

Birds. Satellite transmitters or Platform Terminal Transmitters (PTTs) were deployed on black-browed and white-capped albatrosses, in South African waters. In 2005, 8 PTTs were deployed between 13 July and 20 August on 4 immature black-browed albatrosses and 4 immature white-capped albatrosses (Table 1). In 2006, PTTs were deployed between 24 June and 16 September on 1 immature and 3 adult black-browed albatrosses, and 1 immature whitecapped albatross (Table 1). Based on molecular separation, shy-type albatrosses foraging in southern African waters are most likely to be white-capped albatrosses that breed in New Zealand, with shy albatrosses T. cauta from Australia representing only ca. $5 \%$ of the birds which were killed and returned to port (Abbott et al. 2006, Baker et al. 2007). Therefore, for simplicity, we refer to all shy-type albatrosses tracked in this study as white-capped albatrosses.

Deployed devices were Microwave Telemetry PTTs (30 to $50 \mathrm{~g}$ ) or Sirtrack Kiwisat 202 PTTs (32 g). The former were set to transmit every $90 \mathrm{~s}$ throughout the day, whereas the latter were duty cycled to $12 \mathrm{~h}$ on and $12 \mathrm{~h}$ off. On average, 14 positions $\mathrm{d}^{-1}$ (range: 12 to 21 ) were obtained using Microwave PTTs, and 7 positions $\mathrm{d}^{-1}$ (range: 5 to 11), using Kiwisat PTTs. Birds were caught at sea approximately $40 \mathrm{~km}$ southwest of Cape 
Table 1. Thalassarche melanophrys and T. steadi. Summary of Platform Terminal (satellite transmitter) deployments in 2005 and 2006

\begin{tabular}{|lcc|}
\hline & $\begin{array}{c}\text { No. of } \\
\text { birds }\end{array}$ & $\begin{array}{c}\text { Average in days } \\
\text { (min.-max.) }\end{array}$ \\
\hline $\begin{array}{l}\text { Black-browed (immature) } \\
2005\end{array}$ & 4 & $71(3-123)$ \\
2006 & 1 & 75 \\
Black-browed (adult) & & - \\
2005 & 0 & $52(10-72)$ \\
2006 & 3 & $96(9-139)$ \\
White-capped (immature) & & 35 \\
2005 & 4 & \\
2006 & 1 & \\
\hline
\end{tabular}

Point, South Africa, using a barbless hook, and lifted into the vessel by means of a net. PTTs were attached to the feathers on the bird's mid-back (mantle) using waterproof Tesa tape. Collection of data took place from July to December in 2005 and June to November in 2006. Locations were obtained using the ARGOS (Advanced Research Global Observation Satellite) system. Data received from ARGOS were filtered according to flight speed (maximum velocity was set at 100 $\mathrm{km} \mathrm{h}^{-1}$ ) and ARGOS location quality (all positions with a quality code of A, B and Z were excluded). The tracks were then re-sampled at hourly intervals, assuming that the bird moved along a straight line between points. Spatial analysis (including production of kernels and mapping of density distributions) was performed using Arcview 3.2. This involved the calculation of fixed kernel home range utilization distributions (based on Worton 1989) as grid coverage. A smoothing factor of 1 was used and was kept constant for all individuals using the animal movement extension in Arcview. Kernel density plots have been used successfully in numerous tracking studies to quantify habitat use (e.g. Wood et al. 2000, BirdLife International 2004, Nicholls et al. 2005). The utilization distributions (UD) provide probability contours indicating the relative proportion of the distribution within a particular area.

Other data sources. Seabird tracks were overlaid on fisheries, bathymetric and sea height anomaly data. The position and date of trawls for hake, and setting of surface longlines for tuna Thunnus spp. and swordfish Xiphias gladius, which took place over the same time period as that over which the birds were tracked, were obtained from vessel logbooks and catch returns. Fisheries data were summarized by $1^{\circ}$ grid squares based on the setting location. Discarding typically takes place throughout the day, with the exception of the first set of the day. Etopo-2 bathymetry data were obtained from the National Geophysical Data Center (NGDC). Etopo-2 is a worldwide set of 2 min gridded ocean bathymetry data derived from 1978 satellite radar altimetry of the sea surface (Sandwell 1990). Sea height anomaly (SHA) data, derived from JASON-1, TOPEX, ERS-2, ENVISAT and GFO altimeters and processed at the Stennis Space Center, were obtained from the National Oceanic and Atmospheric Administration (NOAA) (www.aoml.noaa.gov). Maps were generated using SHA data for an average period of $10 \mathrm{~d}$, corresponding to the overlaying bird track (on average, oceanic trips lasted $8.4 \mathrm{~d}$, range: 2 to $20 \mathrm{~d}$, SD: 6.9), using Ocean Data View software for visual representation and Arcview 3.2 for analysis. This information was used to investigate whether birds foraging in the open ocean were likely to be targeting positive or negative anomalies, by comparing the gradient in SHA (the first derivative using spatial analyst in Arcview) at PTT locations with a randomly generated set of points. A 2-tailed $t$-test for unmatched pairs was used to investigate whether the mean SHA for each location along the bird's track was significantly higher than that of the set of random locations.

Relationships between the distribution of blackbrowed and white-capped albatrosses, fisheries and bathymetry were investigated using generalised linear models (GLMs) with a Poisson distribution and logarithmic link function (McCullagh \& Nelder 1989). Genstat 9 (GenStat Committee 2007) was used for model fitting and Akaike's information criterion (AIC) was used to guide model selection (Quinn \& Keough 2002). The logarithm of the parameter $\lambda$ of a Poisson distribution was modelled as a linear combination of explanatory variables, e.g. for 3 explanatory variables, $\log \lambda=a+b_{1} x_{1}+b_{2} x_{2}+b_{3} x_{3}$. Variables were summarized by $1^{\circ}$ grid squares. Initially, the explanatory variables used were number of longline hooks, number of longline sets, number of trawls and bathymetry. The use of longline sets resulted in better fits to the distribution data than the use of longline hooks, and therefore the latter was subsequently excluded from models. The dependent variable used for all the analyses was the time the birds spent in a grid square.

\section{RESULTS}

In 2005, 4 immature black-browed Thalassarche melanophrys and 4 immature white-capped albatrosses T. steadi were tracked for a total of $284 \mathrm{~d}$ (average per bird: 71, SD: 50) and 383 d (average: 96, SD: 59), respectively. In 2006, 1 immature black-browed, 3 adult black-browed and 1 immature white-capped albatrosses were tracked for a total of $75 \mathrm{~d}, 156 \mathrm{~d}$ (average: 52, SD: 36) and $35 \mathrm{~d}$, respectively (Table 1). Birds were tracked for a total distance of $210400 \mathrm{~km}$ (62 $000 \mathrm{~km}$ for immature black-browed, $94000 \mathrm{~km}$ for 
adult black-browed and $54600 \mathrm{~km}$ for immature white-capped albatrosses).

Whilst in the SE Atlantic, adult $(\mathrm{n}=3)$ and immature $(\mathrm{n}=5)$ black-browed albatrosses showed no significant difference in the average and total distances travelled in $24 \mathrm{~h}$ ( $\mathrm{p}=0.1$ and 0.3 , respectively), or any other obvious difference, and data were therefore pooled in further analyses. White-capped albatrosses $(n=5)$ travelled less than half the distance per day (average: $127 \mathrm{~km} \mathrm{~d}^{-1}$, range: 77 to $168 \mathrm{~km} \mathrm{~d}^{-1}$ ) of black-browed albatrosses $(\mathrm{n}=8)$ (average: $303 \mathrm{~km} \mathrm{~d}^{-1}$, range: 123 to $505 \mathrm{~km} \mathrm{~d}^{-1}, t=3.65, \mathrm{p}=0.006$ ).

White-capped albatrosses remained almost exclusively $(98.9 \%$ of time tracked) within 200 nautical miles (n miles) of the coast, mostly (82.6\%) within South Africa's EEZ, and the remainder within Namibian waters (Fig. 1). Time tracked was particularly concentrated on the continental shelf break between 200 and $1000 \mathrm{~m}$, where they spent $79.1 \%$ of their time $(55.3 \%$ at the 200 to $500 \mathrm{~m}$ isobath and $23.8 \%$ at the 500 to $1000 \mathrm{~m}$ isobath) (Fig. 2). Of 5 tracked whitecapped albatrosses, 2 travelled as far north as $20^{\circ} \mathrm{S}$ into Namibian waters, where they spent 70 of 113 $(62.0 \%)$ and 8 of $36 \mathrm{~d}(22.2 \%)$ tracked, respectively. Two white-capped albatrosses each made a brief trip outside of the EEZ. One bird travelled $413 \mathrm{~km}$ in $2 \mathrm{~d}$,

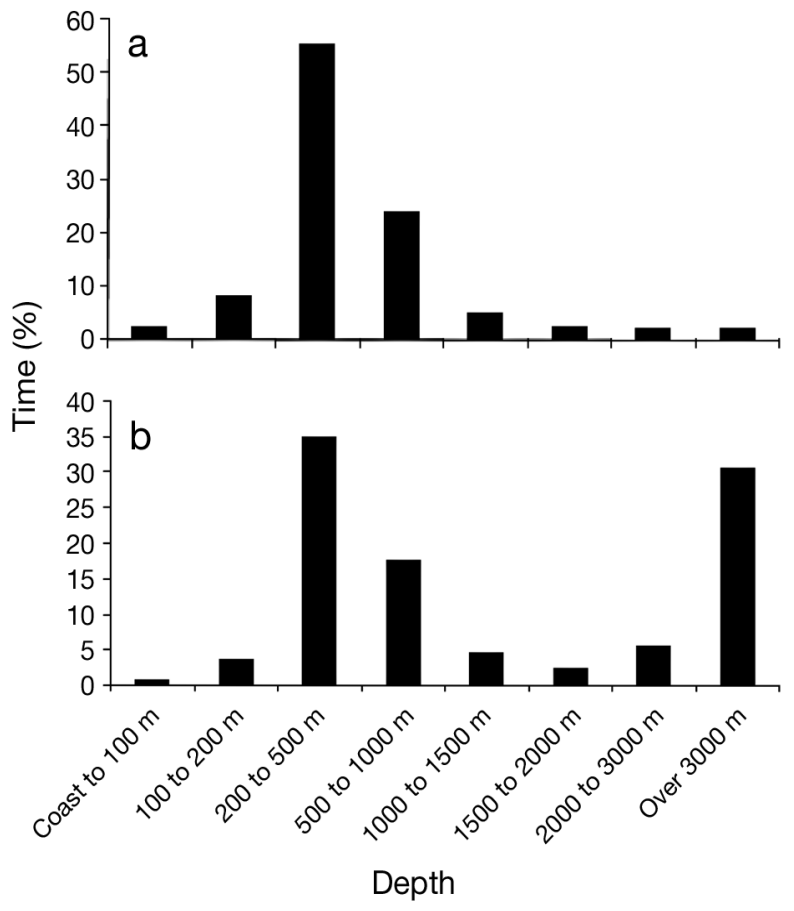

Fig. 2. Thalassarche steadi and T. melanophrys. Percentage of time spent at varying water depths for: (a) white-capped albatrosses and (b) black-browed albatrosses (excluding trans-Atlantic crossings)
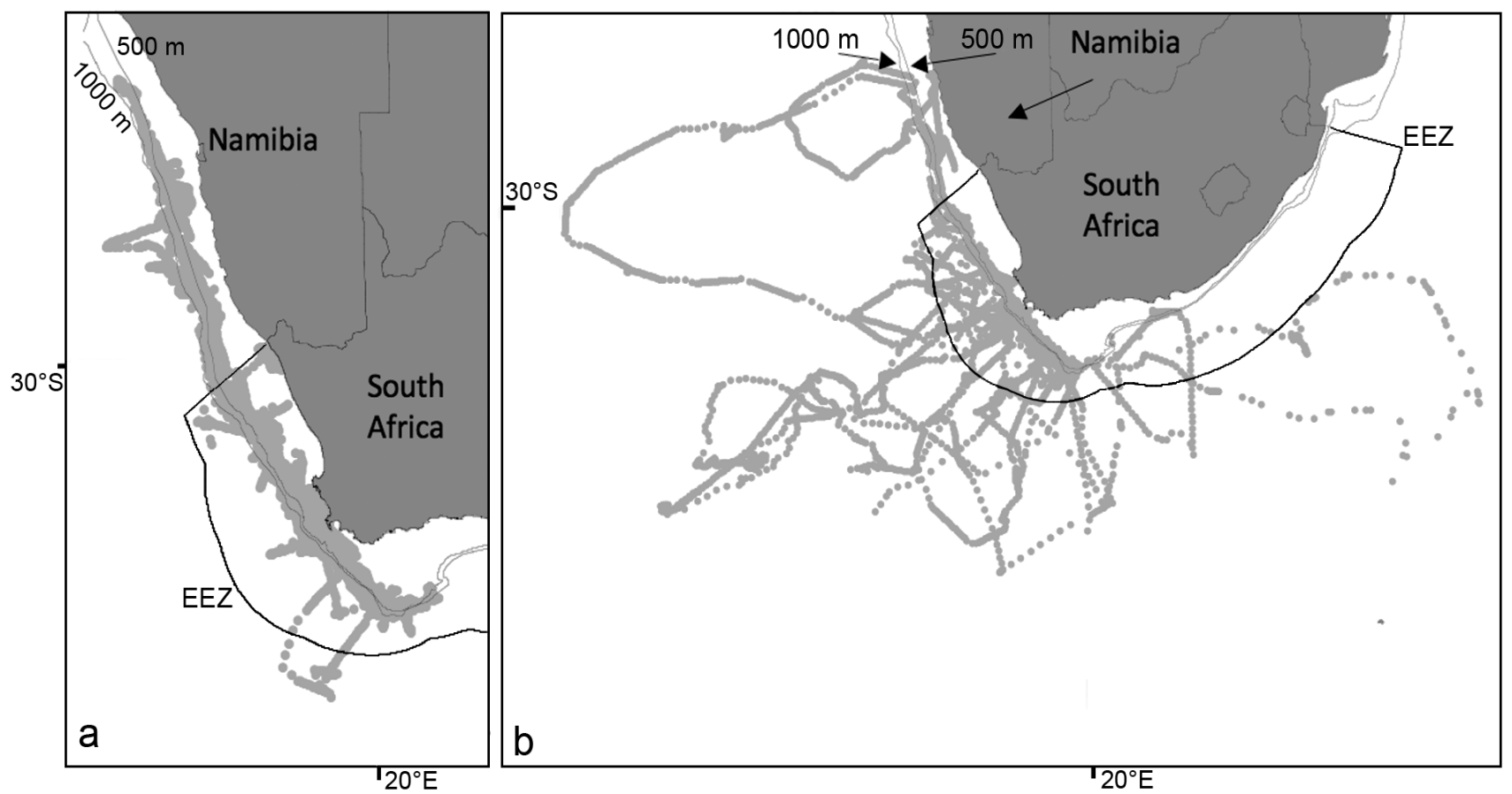

Fig. 1. Thalassarche steadi and T. melanophrys. Filtered locations of (a) white-capped and (b) black-browed albatrosses tracked for 515 and 418 d, respectively, using platform transmitter terminal from July to December in 2005 and June to November in 2006. EEZ: $200 \mathrm{n}$ mile Exclusive Economic Zone; 500 and $1000 \mathrm{~m}$ isobaths are marked 
and the other travelled $2090 \mathrm{~km}$ in $10 \mathrm{~d}$ before returning to the continental shelf.

All black-browed albatrosses tracked for longer than $18 \mathrm{~d}$ in South African waters $(\mathrm{n}=4)$ made frequent trips into deep, oceanic waters (>3000 m), where they spent $30.6 \%$ of their time before returning to forage on the continental shelf, mostly $(34.9 \%)$ in waters between 200 and $500 \mathrm{~m}$ depth (Figs. 1 \& 2). Oceanic trips lasted on average $8.4 \mathrm{~d}$ (range: 2 to $20 \mathrm{~d}$, SD: $6.3, \mathrm{n}=9$ ) covering on average $2540 \mathrm{~km}$ (range: 540 to $5320 \mathrm{~km}, \mathrm{SD}: 1520$ ) or $340 \mathrm{~km} \mathrm{~d}^{-1}$ (range: 100 to $575 \mathrm{~km} \mathrm{~d}^{-1}$ ). Between trips they tended to forage on the continental shelf for an average of $15 \mathrm{~d}$ (range: 4 to $42 \mathrm{~d}$ ). One of the immature birds travelled west across the Atlantic Ocean, leaving the southern Benguela on 23 October 2005 and arriving on the continental shelf off northern Argentina on 11 November 2005, having covered a minimum distance of $9200 \mathrm{~km}$ over $19 \mathrm{~d}$ and at an average speed of $484 \mathrm{~km} \mathrm{~d}^{-1}$. Of the 5 tracked black-browed albatrosses, 2 travelled into Namibian waters as far north as $24^{\circ} \mathrm{S}$ (20 of 75 ,
$26.7 \%$ and 8 of $83,9.6 \%$ ) (Fig. 1). Of the 3 adults tracked, 1 stayed on the continental shelf for the $10 \mathrm{~d}$ for which the device transmitted data. The remaining 2 birds both foraged southwest of Cape Town (33 to $37^{\circ} \mathrm{S}$ ) for 11 and $18 \mathrm{~d}$, then departed from the region on 27 September and 4 October 2006, respectively. Both birds travelled a similar path across the Atlantic Ocean to South Georgia and covered a distance of 7286 and $6444 \mathrm{~km}$ in 21 and $16 \mathrm{~d}$, respectively. Blackbrowed albatrosses spent almost half (average: $50.2 \%$, range: 16.2 to $92.2 \%, \mathrm{SD}: 30.8$ ) of the time tracked within 200 nautical miles of the coast, compared to an average of $98.9 \%$ (range: 97.2 to $100.0 \%$, SD: 1.2) in the case of the white-capped albatross ( $U=$ $0.0, \mathrm{p}=0.004, \mathrm{n}=11$ ).

The $95 \%$ utilization area of black-browed albatrosses in the SE Atlantic (i.e. excluding time spent commuting to the SW Atlantic) was twice as large as that of white-capped albatrosses (Fig. 3). Whitecapped albatrosses covered an area of $241000 \mathrm{~km}^{2}$ (95\% utilization area) and a core area (50\% utilization
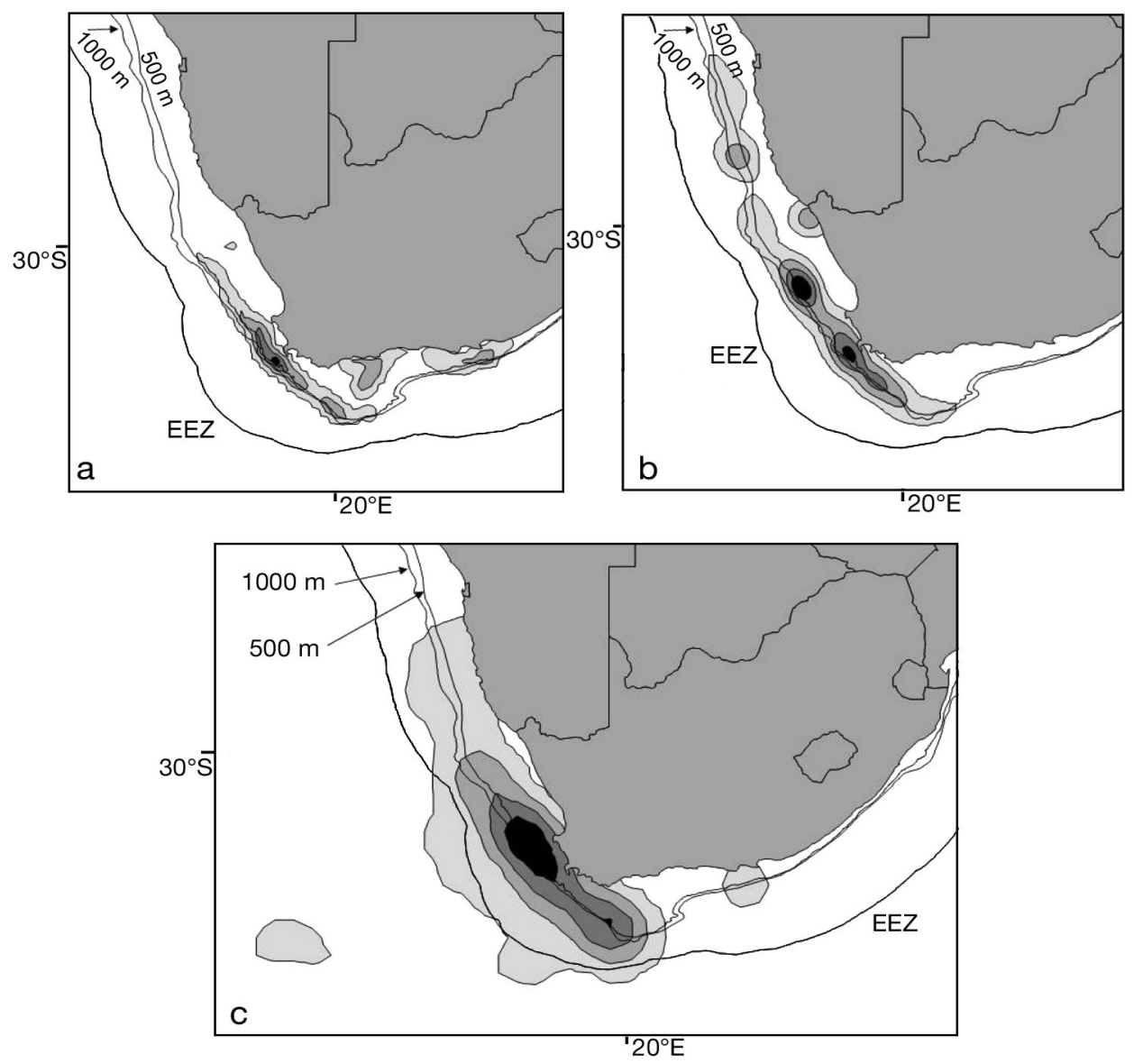

Fig. 3. Thalassarche steadi and T. melanophrys. Map showing the 25, 50, 75 and $95 \%$ (black, dark grey, grey and light grey, respectively) utilization distributions of (a) the trawl fishery, (b) white-capped albatrosses and (c) black-browed albatrosses tracked using satellite-transmitters in the Benguela ecosystem in 2005 and 2006, excluding commuting locations of black-browed albatrosses returning to the SW Atlantic Ocean. EEZ: $200 \mathrm{n}$ mile Exclusive Economic Zone; 500 and $100 \mathrm{~m}$ isobaths are marked 
area) of $27000 \mathrm{~km}^{2}$, whereas black-browed tracks covered a $95 \%$ utilization area of $498000 \mathrm{~km}^{2}$ and a core area of $70000 \mathrm{~km}^{2}$. Comparing the core area $(50 \%$ utilization area) between individuals of each species revealed that white-capped albatrosses were more constrained to the shelf edge (average: $24400 \mathrm{~km}^{2}$, range: 8420 to $36640 \mathrm{~km}^{2}$, SD: $12280 \mathrm{~km}^{2}$ ) compared to black-browed albatrosses (average: $108870 \mathrm{~km}^{2}$, range: 28560 to $145960 \mathrm{~km}^{2}$, SD: $54060 \mathrm{~km}^{2}$ ) (Fig. 4). Patterns were similar between individuals.

\section{Overlap with South African fisheries}

Excluding time spent commuting to the SW Atlantic, black-browed albatrosses spent almost half the amount of time on trawl grounds (average: 39.2\%, range: 16.2 to $60.0 \%, \mathrm{SD}: 18.2)$ compared to whitecapped albatrosses (average: $85.0 \%$, range: 71.4 to $94.3 \%, \mathrm{SD}: 29.8)(U=0.0, \mathrm{p}=0.004, \mathrm{n}=11)$.

In the GLM analysis, the following explained much of the variance in the distribution of white-capped albatrosses: bathymetry (39.1\%), trawl intensity (i.e. number of trawls) $(16.8 \%)$ and longline intensity (i.e. number of sets) $(4.0 \%)$ (Table 2$)$. Trawl intensity and bathymetry explained 30.8 and $27.0 \%$, respectively, of the variance in the distribution of black-browed albatrosses (Table 2). The intensity of longline sets was also significant, but did not account for any further variance and led to an increase in the AIC; hence, any additional explanatory power was negligible.

\section{Relationship with sea surface height}

All immature black-browed albatrosses $(\mathrm{n}=5)$ undertook return trips into oceanic waters on 9 occasions for a total of $76 \mathrm{~d}$ during the $370 \mathrm{~d}$ study period. On these trips, birds tended to follow the edges of warm anti-cyclonic and cold cyclonic eddies where the SHA gradient was the greatest (see Fig. 5 for typical examples ranging from Namibia to the South African east coast). The mean gradient of each PTT location was significantly higher than that of a set of randomly generated locations on 7 of the 9 trips (Table 3). Five of these trips were in a clockwise direction, and 4 were in an anti-clockwise direction.

\section{DISCUSSION}

\section{Influences on white-capped and black-browed albatross distribution}

Although this study is based on a relatively small sample size, it nevertheless shows clear differences in the movements and distribution of white-capped and

Table 2. Thalassarche melanophrys and T. steadi. Summary of results of generalised linear modelling of black-browed and white-capped albatross movements in relation to the presence of trawlers, longliners and bathymetry. Variance is expressed as a percentage

\begin{tabular}{|c|c|c|c|c|}
\hline \multirow[t]{2}{*}{ Parameter } & \multicolumn{2}{|c|}{ Black-browed albatrosses } & \multicolumn{2}{|c|}{ White-capped albatrosses } \\
\hline & Variance & p-value & Variance & p-value \\
\hline Bathymetry & 27.0 & $<0.001$ & 39.1 & $<0.001$ \\
\hline No. of trawls & 30.8 & $<0.001$ & 16.8 & $<0.001$ \\
\hline No. of longline sets & 0 & $<0.001$ & 4.0 & $<0.001$ \\
\hline
\end{tabular}
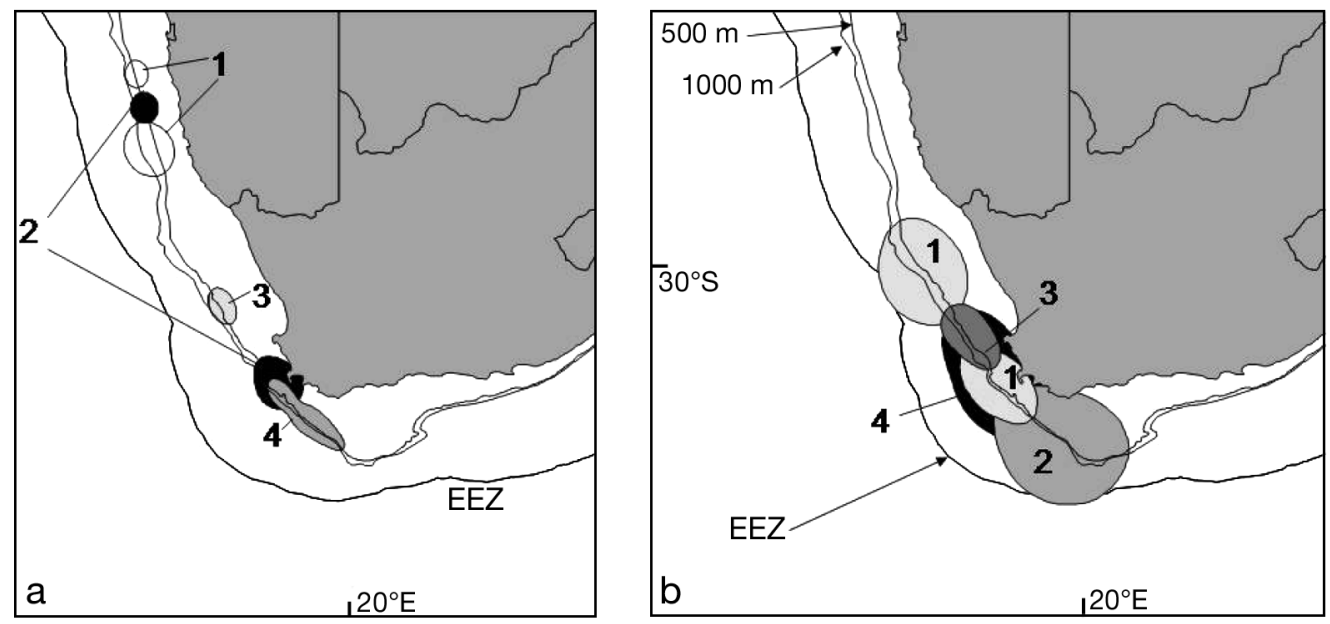

Fig. 4. Thalassarche steadi and T. melanophrys. The 50\% utilization areas (light grey to black; 1 to 4) for (a) white-capped albatrosses $(\mathrm{n}=4)$ and (b) black-browed $(\mathrm{n}=4)$, excluding time spent commuting and only including birds that foraged for $>18 \mathrm{~d}$ in South African waters. EEZ: Exclusive Economic Zone; 500 and $1000 \mathrm{~m}$ isobaths are marked in (b) 
a) Namibia

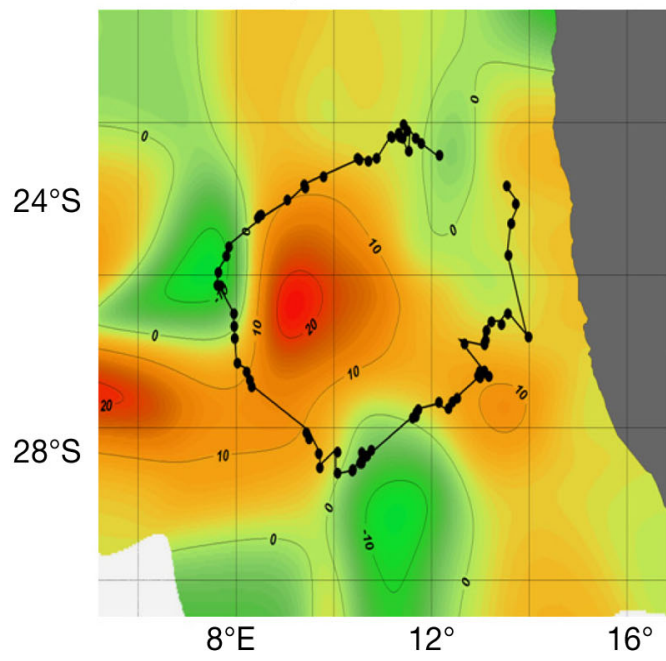

b) South west coast

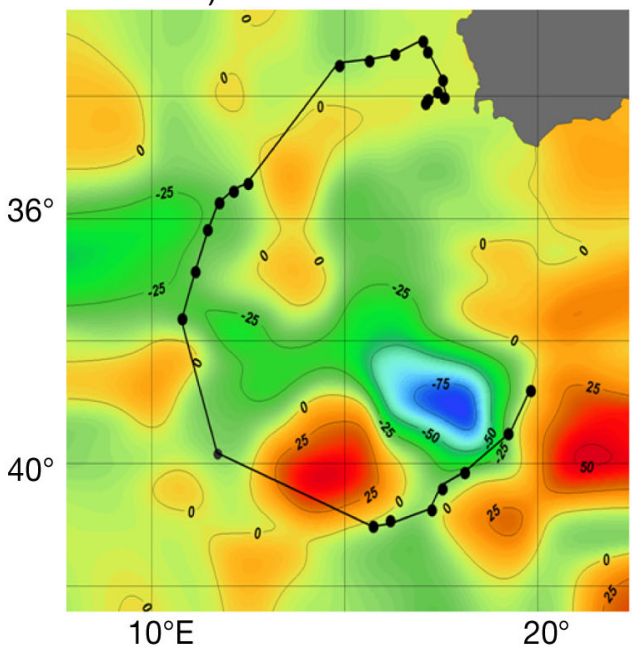

c) South coast

$\mathrm{SSH}$

$(\mathrm{cm})$

75

50

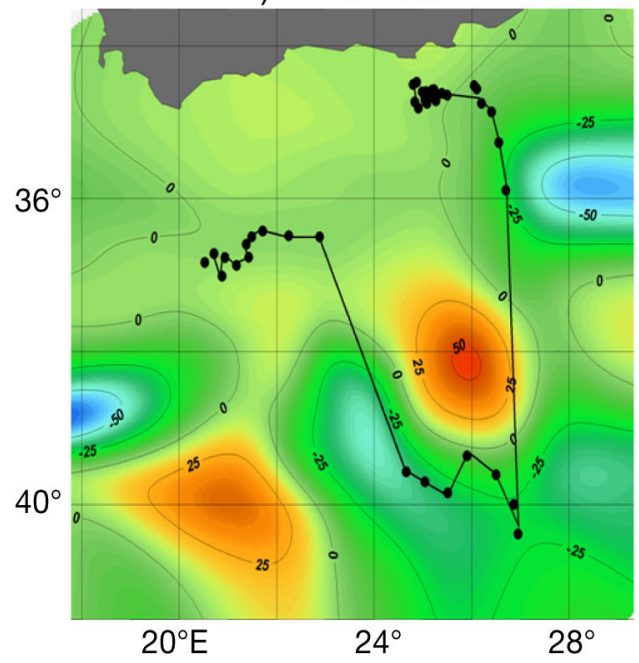

d) East coast

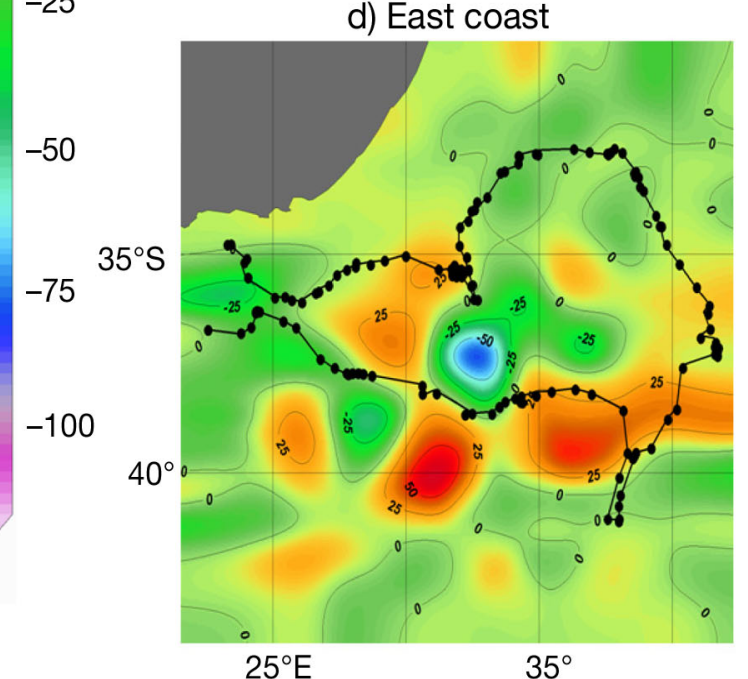

Fig. 5. Thalassarche melanophrys. Black-browed albatross tracks overlaid on $10 \mathrm{~d}$ average sea-surface height (SSH) anomalies in 4 areas: (a) off Namibia, and off South Africa's (b) southwest, (c) south and (d) east coast

Table 3. Thalassarche melanophrys. Characteristics of oceanic trips of black-browed albatrosses (direction and trip length) and summary of $t$-test results testing the difference between the sea height anomaly gradient of birds' tracks compared to a set of random locations

\begin{tabular}{|c|c|c|c|c|c|c|c|c|}
\hline \multirow[t]{2}{*}{ Trip } & \multirow[t]{2}{*}{$t$-value } & \multirow[t]{2}{*}{$\mathrm{p}$-value } & \multirow{2}{*}{$\begin{array}{l}\text { No. of trip } \\
\text { locations }\end{array}$} & \multirow{2}{*}{$\begin{array}{l}\text { No. of random } \\
\text { locations }\end{array}$} & \multirow[t]{2}{*}{ Direction } & \multicolumn{2}{|c|}{ Trip length } & \multirow{2}{*}{$\begin{array}{l}\text { Corr. panel } \\
\text { in Fig. } 5\end{array}$} \\
\hline & & & & & & Days & $\mathrm{km}$ & \\
\hline 1 & 1.94 & 0.053 & 317 & 509 & Anti-clockwise & 11 & 2599 & $\mathrm{~d}$ \\
\hline 2 & 1.3 & 0.198 & 77 & 45 & Anti-clockwise & 5 & 5322 & \\
\hline 3 & 3.37 & 0.002 & 44 & 133 & Anti-clockwise & 20 & 2281 & C \\
\hline 4 & -1.13 & 0.26 & 124 & 199 & Anti-clockwise & 7 & 1724 & \\
\hline 5 & 3.85 & $<0.001$ & 24 & 199 & Clockwise & 3 & 1450 & $\mathrm{~b}$ \\
\hline 6 & 4.76 & $<0.001$ & 59 & 251 & Clockwise & 3 & 4603 & \\
\hline 7 & 4.11 & $<0.001$ & 97 & 351 & Clockwise & 16 & 2414 & \\
\hline 8 & 3.43 & 0.001 & 42 & 248 & Clockwise & 9 & 504 & \\
\hline 9 & 18.73 & $<0.001$ & 79 & 53 & Clockwise & 2 & 1976 & $\mathrm{a}$ \\
\hline
\end{tabular}


black-browed albatrosses in the SE Atlantic. In general, white-capped albatrosses spent most of their time on the trawl grounds, and all tracked birds largely remained within the EEZ. Black-browed albatrosses, on the other hand, made frequent trips into oceanic waters. Of the birds tracked, 2 adults and 1 juvenile left the SE Atlantic on 27 September, 4 October and 23 October, respectively, and travelled across the Atlantic. Both adults arrived at South Georgia on 17 October, which coincides with the onset of breeding in late October (Phillips et al. 2005a). The immature bird remained on the continental shelf off Uruguay until its device stopped transmitting data on 4 November and was therefore unlikely to attempt breeding.

Trawling activity taking place on the continental shelf break off South Africa provides large quantities of high-quality food in the form of discards for both species (Abrams 1983, 1985, Ryan \& Moloney 1988). White-capped albatrosses, which remained almost exclusively along the continental shelf edge, spent most of their time on the hake trawl fishing grounds. Water depth and trawl intensity were, therefore, the strongest predictors of their distribution. There are no published studies on the movements of white-capped albatrosses at other times of year, but tracking of the closely related shy albatross indicates a similar preference for shelf waters, at least during the breeding season (Hedd et al. 2001). The importance of the continental shelf break, including areas outside of the trawl grounds, as a predictor of white-capped albatross distribution indicates that they are also likely to be foraging naturally within South African waters. This is supported by a study during the $1980 \mathrm{~s}$, which found that $60 \%$ of the diet of shy-type albatrosses in South African shelf waters was composed of natural prey (Crawford et al. 1991).

Black-browed albatrosses, by comparison, spent relatively little time on the South African trawling grounds, instead feeding mainly outside of the South Africa EEZ. Nevertheless, while they were within the EEZ the presence of trawlers was the strongest predictor of their distribution. Fishery discards and offal were estimated to make up $80 \%$ of the diet of black-browed albatrosses in South African shelf waters during the 1980s (Crawford et al. 1991). Therefore, it appears that this species exploits fisheries discards to a large extent while close to the South African coast, whereas it presumably feeds to a much greater extent on natural prey whilst on the return trips to oceanic waters.

\section{Reasons for frequent trips into the open ocean}

The return trips undertaken by black-browed albatrosses into oceanic waters are consistent with those reported for wintering adults in the same region by
Phillips et al. (2005a). The only difference is that return trips in this study tended to be shorter in duration (2-20 d vs. 5-38 d). Return trips in the SE Atlantic were typically shorter in duration (2 to $20 \mathrm{~d}$ ). A direct relationship might be anticipated between habitat usage and preference (Matthiopoulos 2003), in which case black-browed albatrosses may simply 'prefer' to forage in the open ocean, alternating with periods on the continental shelf. However, if accessibility is restricted for any reason, utilization in theory becomes a function of preference and accessibility (Matthiopoulos 2003). Since trawling on the continental shelf waters of South Africa provides large quantities of predictable food, we might expect both black-browed and white-capped albatrosses to be attracted to this area. However, regions with high-quality food will also have the highest levels of intra- and inter-specific competition (Ricklefs 1990). It may be that black-browed albatrosses in the Benguela make these periodic sorties into oceanic waters to reduce competition, given the likely dominance behind vessels of the considerably larger white-capped albatrosses. Body size is considered to be an important driver of interference competition in a range of animals (Shoener 1970, Persson 1985, Dickman 1988, Balance et al. 1997, Wanless 1998). Others have postulated that size determines dominance hierarchies in foraging albatrosses (Cherel et al. 2002, Phillips et al. 2005a,b). Wanless (1998) investigated the relationship between size and foraging efficiency and reported that white-capped albatrosses out-competed black-browed albatrosses, particularly for large prey items.

\section{Use of oceanographic features in the open ocean}

Physical and biological processes in the ocean affect the distribution and abundance of plankton, which in turn influences the distribution of prey further up the food chain and hence, ultimately, the distribution of seabirds and marine mammals (Piontkovski et al. 1995, Pakhomov \& McQuaid 1996). Seabirds tend to concentrate at physical oceanographic features, where prey tends to be aggregated at different spatial scales (Haney et al. 1995, Pakhomov \& McQuaid 1996). Results from this study suggest that black-browed albatrosses are not using particular bathymetric zones when far from the South African coast, but instead forage along the margins of meso-scale oceanographic anomalies on their periodic round trips over deep water. Black-browed albatrosses tended to move on the edge of both colder, cyclonic and warmer, anticyclonic eddies. These eddies not only concentrate organisms at their edges, but also exhibit enhanced nutrient levels, which increase primary productivity, 
and are thus areas where food is likely to be in considerably higher concentration than elsewhere in the open ocean (Ansorge et al. 1999).

\section{Implications for conservation}

Both the white-capped and black-browed albatrosses are listed by IUCN as of conservation concern (Near Threatened and Endangered, respectively). Given the overlap between the white-capped albatross distribution and trawling activity in the southern Benguela ecosystem, it is not surprising that this is the most common albatross killed by that fishery (39\% of 18000 birds killed per year) (Watkins et al. 2008). Our results indicate that when black-browed albatrosses forage within the South African EEZ, their distribution is also strongly correlated with the presence of trawlers, and indeed they are the second most common species in bird bycatch (29\%) (Watkins et al. 2008). Interestingly, the occurrence of longline fishing activity accounts for far less variance $(4 \%$ in the case of white-capped albatrosses and none in the case of black-browed albatrosses) compared to that of trawl activities (30.8 and $16.8 \%$, respectively). This is probably because far fewer discards are provided by longliners compared to trawlers, so they are generally less attractive to birds except when longlines are being set. However, longliners remain a serious threat: both species ingest baited hooks during setting and are dragged under and drowned as a result (Ryan et al. 2002, Petersen et al. 2007, S. L. Petersen et al. unpubl. data).

Given the importance of the southern Benguela ecosystem for non-breeding adult and juvenile blackbrowed and white-capped albatrosses, and the high level of interaction with trawl and longline fisheries in the region, several mitigation measures have been considered (MCM 2007). These include the introduction of closed areas where fishing is prohibited, and various means of reducing the attractiveness of vessels to seabirds. Given the dramatic changes in marine ecosystems as a result of past fishing activities (Worm et al. 2003), including dramatic changes in seabird behaviour and distribution resulting from the presence of fishing vessels (Cooper \& Dowle 1976, Ryan \& Moloney 1988, present study), the possibility exists that these management actions could place a further burden on these species.

It has been argued that some scavenging seabirds, such as great skuas in Shetland, and Audouin's gull Larus audouinii and yellow-legged gull L. cachinnans in the Ebro Delta, depend on fisheries discards for successful reproduction when natural prey abundance is reduced (Furness 1987, Oro et al. 1995). However, these are breeding birds with dependent chicks and are therefore tied to a central place. By comparison, the albatrosses in the present study are much less constrained in terms of where they can forage; moreover, they have much lower costs of flight than skuas and larids (Weimerskirch et al. 2000). Furthermore, this study presented evidence that black-browed, and to a lesser extent white-capped, albatrosses targeted natural prey, despite the availability of fisheries discards. Seabirds have evolved in unpredictable, dynamic environments and as a result exhibit highly opportunistic foraging strategies and catholic dietary tastes. The black-browed and white-capped albatrosses in the Benguela Upwelling System are likely to continue adapting their behaviour in response to the changing distribution and abundance of food, much as they would in an entirely natural system. This is supported by evidence from the Ebro Delta, where gulls readily switched their diet back to natural prey after a trawling moratorium was introduced (Oro et al. 1995). Moreover, others have argued that fisheries waste is not an essential part of the diet for most seabird populations (Garthe 1997). Given their extreme life histories, seabird populations are particularly sensitive to any reduction in adult survival (Warham 1996). Therefore, management regimes that reduce additional sources of mortality, such as those resulting from fisheries interactions, are likely to far outweigh the disadvantage of reduced discard and offal availability.

In practical terms, reducing the attractiveness of fishing vessels to seabirds can be achieved effectively in many situations by good offal and discard management (Brothers et al. 1999). Offal and discard management regulations exist for both trawl and longline fisheries in South Africa (MCM 2007). In the case of the trawl fishery, discarding of offal is not permitted during setting when the use of a tori line (a line attached to the highest point on the vessel, with streamers attached to it to keep birds away from the area where the warp enters the water) is not compulsory because of the risk of entanglement with fishing gear. However, discarding offal is not regulated during trawling or between trawls (MCM 2007). It is also possible to equip vessels with macerators that allow finer waste to be discharged, which sinks much more rapidly, or holding tanks that allow retention of waste on board, both of which greatly reduce the attractiveness of fishing vessels to larger seabirds in particular (Wanless 1998, MCM 2007). Existing mandatory South African longline fishery regulations require that the discharge of offal must not occur during setting, and, during hauling, it must take place on the opposite side of the vessel from the hauling station, where birds could get hooked (MCM 2007). An alternative means of manag- 
ing fishing in the South African EEZ would be to introduce a system of closed areas. Results from our study, however, suggest that this would be ineffective, given the very large foraging ranges and high mobility of the tracked birds.

Acknowledgements. Satellite tracking devices were donated by LPO, the French BirdLife partner and the British Antarctic Survey (BAS). A special thank you to Harry Dilly, Barrie Rose, David Gremillet, Etienne de Villiers, Mike Meÿer, Cape Town pelagics and Zest for Birds for their help in deploying satellite devices on albatrosses at sea off Cape Point in 2005 and 2006. Marine and Coastal Management provided funding for the ARGOS time required for receiving positional data from albatross satellite transmitters. The fisheries data used in this paper were made available by Marine and Coastal Management, Department of Environmental Affairs and Tourism, South Africa. Financial support was received from the BCLME (Benguela Current Large Marine Ecosystem) Programme, WWF, BirdLife International and IAATO (International Association of Antarctic Tour Operators), Seachange Programme of the National Research Foundation, The Albatross Task Force, BirdLife International, the Percy FitzPatrick Institute for African Ornithology and the National Research Foundation. Thank you to Maria Honig, who commented on an earlier draft.

\section{LITERATURE CITED}

Abbott CL, Double MC, Gales R, Baker GB, Lashko A, Robertson CJR, Ryan PG (2006) Molecular provenance analysis for shy and white-capped albatrosses killed by fisheries interactions in Australia, New Zealand and South Africa. Conserv Genet 7:531-542

Abrams RW (1983) Pelagic seabirds and trawl-fisheries in the southern Benguela Current region. Mar Ecol Prog Ser 11: 151-156

> Abrams RW (1985) Pelagic seabird community structure in the southern Benguela region: Changes in response to man's activities? Biol Conserv 32:33-49

Ansorge IJ, Froneman PW, Pakhomov EA, Lutjehams JRE, Perissinotto R, van Ballegooyen RC (1999) Physical-biological coupling in the waters surrounding the Prince Edward Islands (Southern Ocean). Polar Biol 21:135-145

Baker GB, Double MC, Gales R, Tuck GN and others (2007) A global assessment of the impact of fisheries-related mortality on shy and white-capped albatrosses: conservation implications. Biol Conserv 137:319-333

Balance LT, Pitman RL, Reilly SB (1997) Seabird community structure along a productivity gradient: importance of competition and energetic constraint. Ecology 78: $1502-1518$

Barnes KN, Ryan PG, Boix-Hinzen C (1997) The impact of the hake Merluccius spp. longline fishery off South Africa on procellariiform seabirds. Biol Conserv 82:227-234

BirdLife International (2004) Tracking ocean wanderers: the global distribution of albatrosses and petrels. Results from the Global Procellariiform Tracking Workshop 1-5 September 2003, Gordons Bay, South Africa. BirdLife International, Cambridge

BirdLife International (2008) IUCN Red List of threatened species. www.iucnredlist.org

Brothers N, Gales R, Hedd A, Robertson G (1998) Foraging movements of the shy albatross Diomedea cauta breeding in Australia: implications for interactions with longline fisheries. Ibis 140:446-457

Brothers NP, Cooper J, Løkkeborg S (1999) The incidental catch of seabirds by longline fisheries: worldwide review and technical guidelines for mitigation, preliminary version. FAO Fisheries Circular No. 937, FAO, Rome

CCAMLR (Convention for the Conservation of Antarctic Marine Living Resources) (2002) Schedule of conservation measures in force, 2002/03. CCAMLR, Hobart, p 45-45

Cherel Y, Weimerskirch H, Trouvé C (2002) Dietary evidence for spatial foraging segregation in sympatric albatrosses (Diomedea spp.) rearing chicks at Iles Nuageuses, Kerguelen. Mar Biol 141:1117-1129

Cooper J, Dowle JE (1976) Seasonal and spatial distribution of some procellariiform seabirds in southern African waters. Ardea 64:72-79

Crawford RJM, Ryan PG, Williams AJ (1991) Seabird consumption and production in the Benguela and western Agulhas ecosystems. S Afr J Mar Sci 11:357-375

Croxall JP, Gales R (1998) An assessment of the conservation status of albatrosses. In: Robertson G, Gales R (eds) Albatross biology and conservation. Surrey Beatty \& Sons, Chipping Norton, p 46-65

Croxall JP, Prince P, Rothery P, Wood AG (1998) Population changes in albatrosses at South Georgia. In: Robertson G, Gales R (eds) Albatross biology and conservation. Surrey Beatty \& Sons, Chipping Norton, p 69-83

Croxall JP, Silk RD, Phillips RA, Afanasyey V, Briggs DR (2005) Global circumnavigations: tracking year-round ranges of non-breeding albatrosses. Science 307:249-250

> Dickman CR (1988) Body size, prey size and community structure in insectivorous mammals. Ecology 69:569-580

Duffy DC, Siegfried WR, Jackson S (1987) Seabirds as consumers in the southern Benguela system. S Afr J Mar Sci 5:771-790

Furness RW (1987) Effects of changes in whitefish net-mesh size on scavenging seabird ecology. NCC Chief Scientist Directorate Report, JNCC Report No. 133

Furness RW, Hudson AV, Ensor K (1988) Interaction between scavenging seabirds and commercial fisheries around the British Isles. In: Burger J (ed) Seabirds and other marine vertebrates. Competition, predation and other interaction. Columbia University Press, New York, p 240-268

Furness RW, Ensor K, Hudson AV (1992) The use of fishery waste by gull populations around the British Isles. Ardea 80:105-113

> Garthe S (1997) Influence of hydrogaphy, fishing activity, and colony location on summer seabird distribution in the south-eastern North Sea. ICES J Mar Sci 54:566-577

Garthe S, Camphuysen KCJ, Furness RW (1996) Amounts of discards by commercial fisheries and their significance as food for seabirds in the North Sea. Mar Ecol Prog Ser 136:1-11

GenStat Committee (2007) The guide to GenStat ${ }^{\circledR}$, Release 10, Part 2: statistics. VSN International, Hemel Hempstead

González-Zevallos D, Yorio P (2006) Seabird use of discards and incidental captures at the Argentine hake trawl fishery in the Golfo San Jorge, Argentina. Mar Ecol Prog Ser 316:175-183

- Haney JC, Haury LR, Mullineaux LS, Fey CL (1995) Seabird aggregation at a deep North Pacific seamount. Mar Biol 123:1-9

> Hedd A, Gales R, Brothers NP (2001) Foraging strategies of shy albatross Thalassarche cauta breeding at Albatross Island, Tasmania, Australia. Mar Ecol Prog Ser 224: 267-282

Hunt GL, Schneider DC (1987) Scale dependent processes in 
the physical and biological environment of marine birds. In: Croxall JP (ed) Seabirds: feeding ecology and role in marine ecosystems. Cambridge University Press, Cambridge, $\mathrm{p} 7-41$

Lack D (1968) Ecological adaptations for breeding birds. Menthuen, London

Matthiopoulos J (2003) The use of space by animals as a function of accessibility and preference. Ecol Model 159: 239-268

McCullagh P, Nelder JA (1989) Generalised linear models, 2nd edn. Chapman \& Hall, London

MCM (Marine and Coastal Management) (2007) Draft South African national plan of action for reducing the incidental catch of seabirds in longline fisheries. MCM, Department of Environmental Affairs and Tourism, Cape Town. Available at: www.environment.gov.za

Nel DC, Lutjeharms JRE, Pakhomov EA, Ansorge IJ, Ryan PG, Klages NTW (2001) Exploitation of mesoscale oceanographic features by grey-headed albatross Thalassarche chrysostoma in the southern Indian Ocean. Mar Ecol Prog Ser 217:15-26

Nicholls DG, Robertson CJR, Naef-Daenzer B (2005) Evaluating distribution modelling using kernel functions for northern royal albatrosses (Diomedea sanfordi) at sea off South America. Notornis 52:223-235

Oro D, Bosch M, Ruiz X (1995) Effects of trawling moratorium on the breeding success of the yellow-legged gull Larus cachinnans. Ibis 137:547-549

Pakhomov EA, McQuaid CD (1996) Distribution of surface zooplankton and seabirds across the Southern Ocean. Polar Biol 16:271-286

Persson L (1985) Asymmetrical competition: Are larger animals competitively superior? Am Nat 126:261-266

Petersen SL, Nel DC, Omardien A (2007) Towards an ecosystem approach to longline fisheries in the Benguela: an assessment of impacts on seabirds, sea turtles and sharks. WWF South Africa Report Series-2007/Marine/001, WWF, Stellenbosch

Phillips RA, Petersen MK, Lilliendahl K, Solmundsson J, Hamer KC, Camphuysen CJ, Zonfrillo B (1999) Diets of northern fulmars Fulmarus glacialis: Reliance on commercial fisheries? Mar Biol 135:159-170

Phillips RA, Silk RD, Croxall JP, Bennett VJ, Afanasyev V (2005a) Summer distribution and migration of non-breeding albatrosses: individual consistencies and implications for conservation. Ecology 86:2386-2396

Phillips RA, Silk RD, Croxall JP (2005b) Foraging and provisioning strategies of the light-mantled sooty albatross at South Georgia: competition and co-existence with sympatric pelagic predators. Mar Ecol Prog Ser 285:259-270

Piontkovski SA, Williams R, Malnik TA (1995) Spatial heterogeneity, biomass and size structure of plankton of the Indian Ocean: some general trends. Mar Ecol Prog Ser $117: 219-227$

> Poncet S, Robertson G, Phillips RA, Lawton K, Phalan B, Trathan PN, Croxall JP (2006) Status and distribution of wandering, black-browed and grey-headed albatrosses breeding at South Georgia. Polar Biol 29:772-781

Prince PA, Huin N, Weimerskirsh H (1994) Diving depths of albatrosses. Antarct Sci 6:353-354

Prince PA, Croxall JP, Trathnan PN, Wood AG (1998) The pelagic distribution of South Georgia albatrosses and their relationship with fisheries. In: Robertson G, Gales R (eds) Albatross biology and conservation. Surrey Beatty \& Sons,
Chipping Norton, p 137-167

Quinn GP, Keough MJ (2002) Experimental design and data analysis for biologists. Cambridge University Press, Cambridge

Read AJ (2007) Do circle hooks reduce the mortality of sea turtles in pelagic longlines? A review of recent experiments. Biol Conserv 135:155-169

Ricklefs RE (1990) Seabird life histories and the marine environment: some speculations. Colon Waterbirds 13:1-6

Ryan PG, Moloney CL (1988) Effect of trawling on bird and seal distributions in the southern Benguela region. Mar Ecol Prog Ser 45:1-11

Ryan PG, Keith DG, Kroese M (2002) Seabird bycatch by tuna longline fisheries off southern Africa. S Afr J Mar Sci 24:103-110

Sandwell DT (1990) Geophysical applications of satellite altimetry. Rev Geophys (Suppl):132-137

Schoener TW (1970) Size patterns in west India Anolis lizards. II. Correlations with the sizes of particular sympatric species: displacement and convergence. Am Nat 104:155-174

Shannon LV, Field JG (1985) Are fish stocks food-limited in the southern Benguela pelagic ecosystem? Mar Ecol Prog Ser 22:7-19

Silverman BW (1986) Density estimation for statistics and data analysis. Chapman \& Hall, London

Sullivan BJ, Reid TA, Bugoni L (2006) Seabird mortality on factory trawlers in the Falkland Islands and beyond. Biol Conserv 131:495-504

Votier SC, Furness RW, Bearhop S, Crane JE and others (2004) Changes in fisheries discard rates and seabird communities. Nature 427:727-730

Wahl TR, Heinemann D (1979) Seabirds and fishing vessels: co-occurrence and attraction. Condor 81:390-396

Wanless RM (1998) Does size matter? Feeding hierarchies and the importance of fishery discards for pelagic seabirds in the southern Benguela. BSc honours project, Department of Zoology, University of Cape Town

Warham J (1996) The behaviour, population biology and physiology of the petrels. Academic Press, London

Watkins BP, Petersen SL, Ryan GP (2008) Interactions between seabirds and deep-water hake trawl gear: an assessment of impacts in South African waters. Anim Conserv 11:247-254

Weimerskirch H, Jouventin P (1998) Changes in population sizes and demographic parameters of six albatross species breeding on the French sub-Antarctic islands. In: Robertson G, Gales R (eds) Albatross biology and conservation. Surrey Beatty and Sons, Chipping Norton, p 84-91

Weimerskirch $H$, Salamolard M, Sarrazin F, Jouventin P (1993) Foraging strategy of wandering albatross through the breeding season: a study using satellite telemetry. Auk 110:325-342

Weimerskirch H, Guionnet T, Martin J, Shaffer SA, Costa DP (2000) Fast and fuel efficient? Optimal use of wind by flying albatrosses. Proc R Soc Lond 267:1869-1874

Wood AG, Naef-Daenzer B, Prince PA, Croxall JP (2000) Quantifying habitat use in satellite-tracked pelagic seabirds. Application of kernel estimation to albatross locations. J Avian Biol 31:278-286

Worm B, Lotze HK, Myers RA (2003) Predator diversity hotspots in the blue ocean. Proc Natl Acad Sci USA 100: 9884-9888

Worton BJ (1989) Kernel methods for estimating the utilization distribution in home-range studies. Ecology 70: 164-168

Submitted: April 30, 2008; Accepted: August 13, 2008

Proofs received from author(s): October 10, 2008
Editorial responsibility: Rory Wilson,

Swansea, UK 